\title{
TU/e EmonONEN

\section{Demonstration of traffic control and WDM routing in all-optical data vortex node}

\section{Citation for published version (APA):}

Jung, H. D., Tangdiongga, E., \& Koonen, A. M. J. (2008). Demonstration of traffic control and WDM routing in all-optical data vortex node. In Conference on Lasers and Electro-Optics, 2008 and 2008 Conference on Quantum Electronics and Laser Science : CLEO/QELS 2008; 4 - 9 May 2008, San Jose, [CA] (pp. CFF1-1/2). [4550969] Institute of Electrical and Electronics Engineers. https://doi.org/10.1109/CLEO.2008.4550969

DOI:

10.1109/CLEO.2008.4550969

Document status and date:

Published: 15/09/2008

\section{Document Version:}

Publisher's PDF, also known as Version of Record (includes final page, issue and volume numbers)

\section{Please check the document version of this publication:}

- A submitted manuscript is the version of the article upon submission and before peer-review. There can be important differences between the submitted version and the official published version of record. People interested in the research are advised to contact the author for the final version of the publication, or visit the $\mathrm{DOI}$ to the publisher's website.

- The final author version and the galley proof are versions of the publication after peer review.

- The final published version features the final layout of the paper including the volume, issue and page numbers.

Link to publication

\section{General rights}

Copyright and moral rights for the publications made accessible in the public portal are retained by the authors and/or other copyright owners and it is a condition of accessing publications that users recognise and abide by the legal requirements associated with these rights.

- Users may download and print one copy of any publication from the public portal for the purpose of private study or research.

- You may not further distribute the material or use it for any profit-making activity or commercial gain

- You may freely distribute the URL identifying the publication in the public portal.

If the publication is distributed under the terms of Article 25fa of the Dutch Copyright Act, indicated by the "Taverne" license above, please follow below link for the End User Agreement:

www.tue.nl/taverne

Take down policy

If you believe that this document breaches copyright please contact us at:

openaccess@tue.nl

providing details and we will investigate your claim. 


\title{
Demonstration of Traffic Control and WDM Routing in All-Optical Data Vortex Node
}

\author{
Hyun-Do Jung, Eduward Tangdiongga, and A.M.J. Koonen \\ COBRA Research Institute, Eindhoven University of Technology, 5600 MB, Eindhoven, NL (jhd94@ieee.org)
}

\begin{abstract}
We demonstrate all-optical traffic control and self-routing of WDM optical packets in a cascaded two-node all-optical Data Vortex switching node. In the experiment, WDM optical packets are successfully routed while maintaining a BER of $10^{-10}$ or better.

(C)2008 Optical Society of America

OCIS codes: (230.3750) Optical logic devices; (060.4259) Networks, packet-switched
\end{abstract}

\section{Introduction}

The Data Vortex routing structure suggested for the optical packet switching technique approaches the challenges such as the absence of robust optical buffers and the contention resolution from a simple routing logic and the viewpoint of the routing structure. So far, several researches [1-3] have been reported. We demonstrate all-optical traffic control and self-routing of WDM encoded optical packets carrying 40Gb/s payload signal in a cascaded two-node all-optical Data Vortex node by all-optical header processing which is different from the electro-optic header processing used at the previous reported researches.

\section{Structure of all-optical Data Vortex switching node}

The proposed all-optical Data Vortex switch node[4] is shown in Fig. 1, which consists of two MZISOAs. The upper and lower MZI-SOA acts as an AND optical logic gate and an $1 \times 2$ optical switch, respectively. In an optical packet, a WDM scheme is used to carry the payload and header of an optical packet. In a WDM packet encoding scheme, each wavelength channel carries a single header bit on a time slot, and each node in a Data Vortex router decodes a specific header bit in a binary tree fashion.

If a WDM encoded optical packet comes into the proposed switch node, a portion of the signal is tapped into the upper MZI-SOA. Then the specific header signal is extracted by the passive optical bandpass filter for the header processing. The upper MZI-SOA performs a header processing by the extracted header and the control signal from inner node and gives a routing signal for the lower MZI-SOA. This routing signal controls the switching function of the lower MZI-SOA gate.

\section{Experiment and Results}

The experiment setup shown in Fig. 2 consists of two parts: the optical packet generator and the cascaded all-optical Data Vortex node. In the packet generator, a $10 \mathrm{~Gb} / \mathrm{s}$ mode locking laser $\left(\lambda_{\mathrm{p}}=1560 \mathrm{~nm}\right)$ carrying the payload data is optically multiplexed to $40 \mathrm{~Gb} / \mathrm{s}$ to generate the optical payload. Two header channels $\left(\lambda_{2}=1553.3 \mathrm{~nm}\right.$ and $\left.\lambda_{3}=1554.1 \mathrm{~nm}\right)$ are combined with the $40 \mathrm{~Gb} / \mathrm{s}$ optical payload to compose the input optical packet sequence. This optical packet and the control signal $\left(\lambda_{1}=1552.5 \mathrm{~nm}\right)$ are applied separately to the node- 1 . In the switching nodes, the each optical packet in the input packet sequence is routed separately according to the traffic control signal and the extracted header information.

Figure 3 shows the routing results. In node-1, the initial input sequence has the data set of " 101100 100011001100110011000000 ". As mentioned previously, a portion of the input packet is tapped and sent to the upper MZI-SOA for the header processing. In node-1, the wavelength of the bandpass filter is set to the same as the header channel $1\left(\lambda_{2}=1553.3 \mathrm{~nm}\right)$. The extracted header signal interacts with the traffic control signal according to the AND logic operation. The output routing signal has only "on" bits when both header and control bit are simultaneously "on". The input packet signal heading to the lower MZI-SOA was routed to either the SOUTH or the EAST output port in accordance with these routing bits. The optical packets switched to the EAST are sent to the input port of node- 2 and are routed according to the header channel $2\left(\lambda_{3}=1554.1 \mathrm{~nm}\right)$ and the traffic control generated from node- 1 in the same way at node-1. In the experiment, WDM optical packets are successfully routed while maintaining a bit-error rate of $10^{-10}$ or better at each node as shown in Fig. 3 . 


\section{CFF1.pdf}

\section{References}

[1] C. Reed, "Multiple level minimum logic network," in U.S. Patent 5996020 (1999).

[2] Q. Yang, K. Bergman, G. D. Hughes, and F. G. Johnson, "WDM packet routing for high-capacity data networks," J. Lightw. Technol., 19, 1420-1426 (2001).

[3] A. Shacham, B. A. Small, O. Liboiron-Ladouceur, and K. Bergman, "A fully implemented 12×12 data vortex optical packet switching interconnection network," J. Lightw. Technol., 23, 3066-3075 (2005).

[4] H.-D. Jung, I. T. Monry, A.M.J. Koonen, and E. Tangdiongga, "All-Optical Data Vortex Node Using an MZI-SOA Switch Array,” IEEE Photon. Technol. Lett., 22, 1777-1779 (2007)

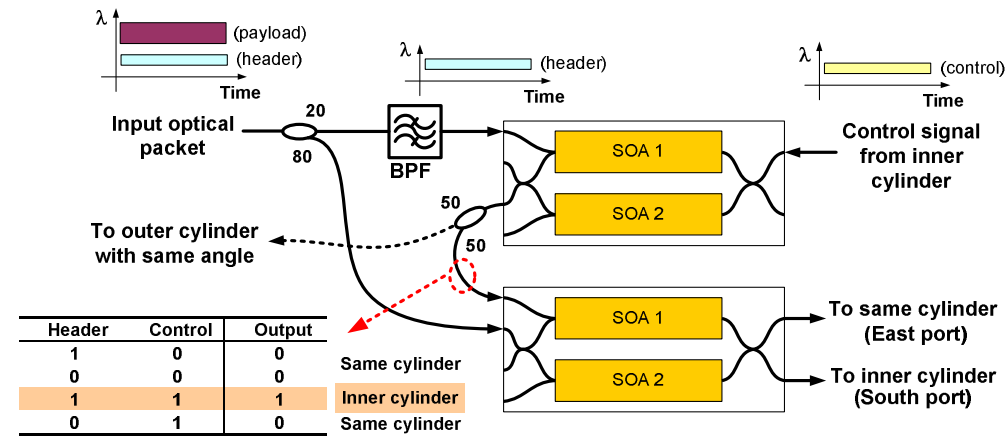

Fig. 1 Proposed all-optical Data Vortex switch node employing MZI-SOAs

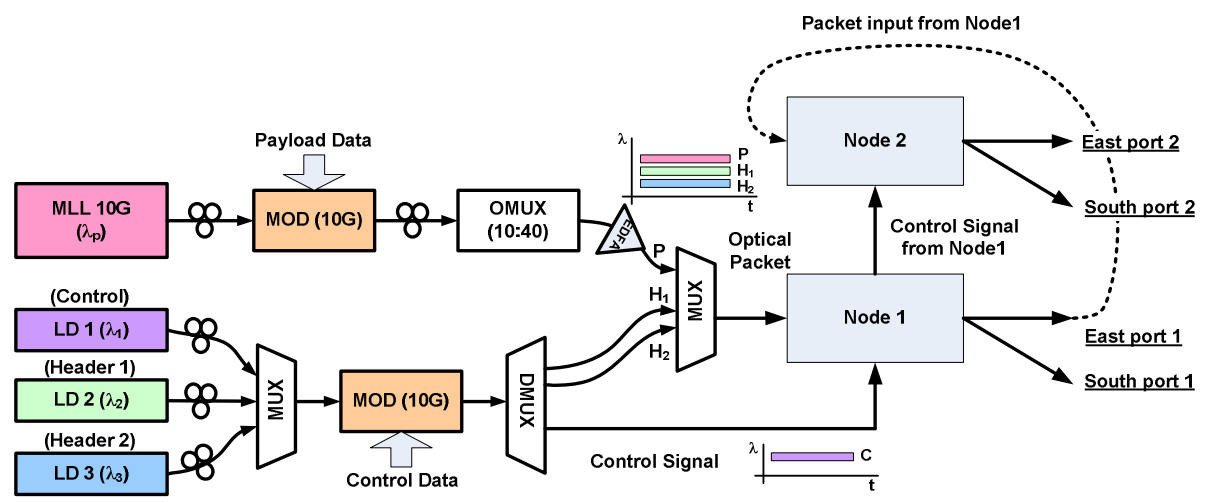

Fig. 2 Experiment setup for traffic control and WDM routing

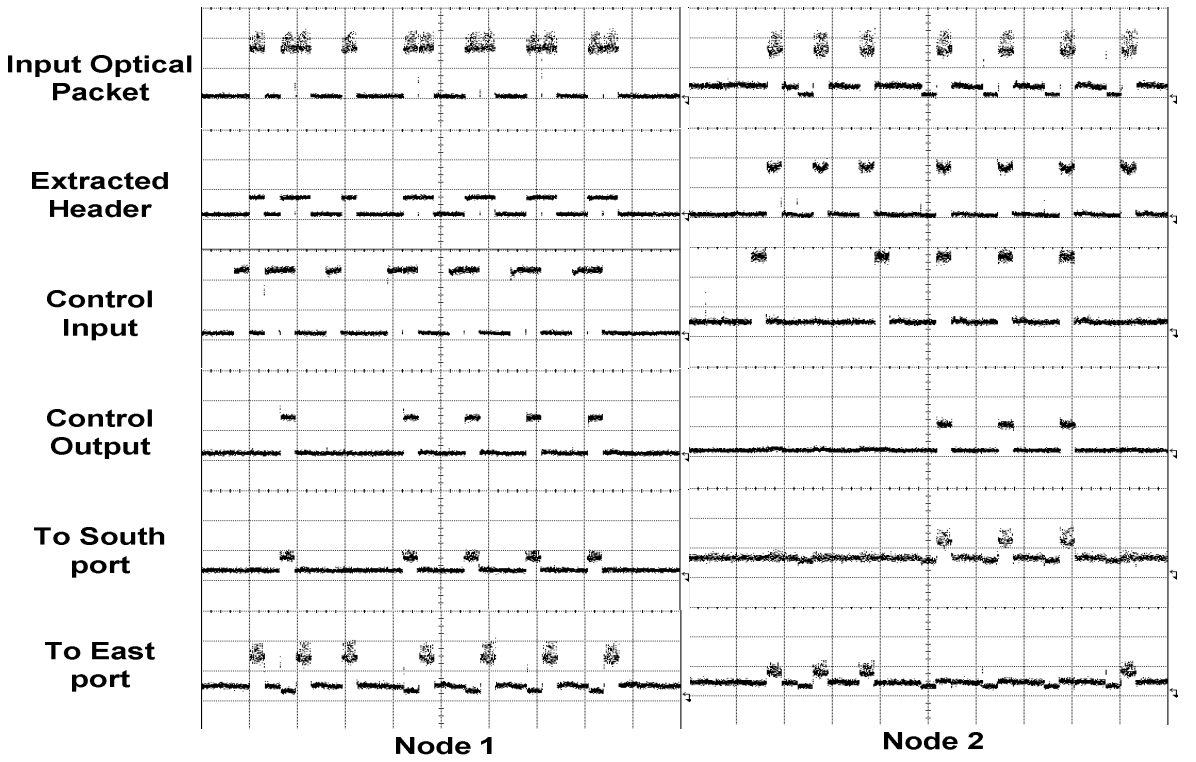

Fig. 3 Routing results at each node 